\title{
Editorial on the BREXIT Forum
}

\author{
Paul J. J. Welfens ${ }^{1,2,3}$
}

Published online: 24 October 2016

(C) Springer-Verlag Berlin Heidelberg 2016

June 23rd, 2016, saw the historical second British referendum on EU membership, 40 years after the first. The majority for an exit came as a surprise to many economic and political observers. A lively debate explores the motivations behind the vote and its eventual significance for the United Kingdom and the European Union. In this Forum, Harold James, Cillian Ryan and Paul Welfens share their insights into Brexit, a topic set to dominate EU and UK discussions into 2019 and beyond.

The referendum's majority in favour of leaving the European Union marks a rather surprising outcome which few economists anticipated (I myself was sceptical and wrote, in a contribution to the AICGS/Johns Hopkins University advisor section on March 30th, that BREXIT was likely and to some extent I followed the arguments of Gideon Rachman in the Financial Times; http:/www.aicgs.org/issue/british-referendum-pains-and-the-eu-implications-of-brexit/). It is fairly clear that voters in the UK referendum cast their votes based on considerations which went far beyond just the issue of EU membership and this was certainly a problem since the pro-EU position of the Cameron government invited a counter-reaction from many voters who were dissatisfied with both EU membership and the fiscal consolidation course that government had pursued over many years.

Prior to the referendum, Opinion Research asked British voters about key issues relevant for voting behaviour. The basic view in the context of the BREXIT decision, according to Opinion Research (as quoted in the Guardian) was that the key topics, i.e. those getting more than $50 \%$ of nominations, were immigration and problems with the National Health System - the latter indirectly linked to immigration to the extent that perceived longer waiting periods were attributed to the increased number of

Paul J. J. Welfens

welfens@wiwi.uni-wuppertal.de; welfenspjj@aol.com

1 European Institute for International Economic Relations, University of Wuppertal (EIIW),

Rainer-Gruenter-Str. 21, D-42119 Wuppertal, Germany

2 Schumpeter School of Business and Economics, University ofWuppertal, Rainer-Gruenter-Str. 21, D-42119 Wuppertal, Germany

3 AICGS/Johns Hopkins University, Washington, DC, USA 
immigrants. As regards the third most important topic, other important issues according to the Opinion Research findings were the relationship of the UK to the EU, economic issues, poverty problems, the housing market, inequality, low wages and unemployment. Respondents could designate several problems as being a 'top 3' issue.

This general view was somewhat different from the question of what the three most important issues for you and your family are. The most frequent nominations were the National Health System (with more than 50 percent), the economy, low wages, immigration (each with more than 20 percent), the relationship between the UK and the European Union, housing, education and poverty/inequality. Here, one could indirectly see that the Cameron government's massive cuts in terms of fiscal transfers to local communities were considered to be a major problem. At the same time, rising rents and housing market problems were not so much an EU-related problem, rather a lack of regional and local community planning - and again insufficient funding for urban housing projects - were key deficiencies. European Parliament elections are known to have often served a scapegoat function in the sense that voters voiced less concerns about critical EU politics, but rather indicated frustrations about national policies.

In retrospect, the findings of Opinion Research are crucial for the new May government which has already indicated that additional government funding for new housing projects will be high on the agenda. The new government has indicated its willingness to seek a hard BREXIT - this is the interpretation of most observers of May's speech at the Birmingham Tory Party convention in early October. What can one make of the historical referendum decision from an analytical perspective?

Harold James emphasizes that the UK has never developed a strong European identity - with the Euro integration process, the UK felt increasingly isolated, the mismanagement of the Euro crisis then undermined both the Eurozone's and the EU's reputation. The inability of the Euro countries to quickly restore stability in the Eurozone reinforced the feeling of British anti-Euro critics who were quick to point out "we told you so". Harold James points out that only the UK and Denmark have a euro-opting-out clause so that all other EU countries would be expected to join the Eurozone sooner or later; and he also shows that two countries, one of which is the UK, show a relative majority of respondents in the EU Commission's Eurobarometer surveys which expects to fare better outside the EU than within. The referendum result can be explained by a specific coalition of actors from the right - emphasizing sovereignty - and from the left - with a focus on anti-EU and anti-globalization sentiments. Harold James argues that the populist political wave is affecting major EU countries and thus this new political current is a serious development. An important new aspect emphasized in his analysis concerns the dilemma of sovereignty - as a postBREXIT UK wants to assert full sovereignty, it is unclear who will really be the winner of the power struggle and major conflicts could emerge in this context. In the view of James, the migration issue was not really decisive for the referendum's outcome. As regards the new May government, he points out the clear alternatives of a soft BREXIT versus a hard BREXIT on the one hand, on the other hand that Eurozone countries might consider new reform elements and now pick up the issue of a joint fiscal capacity; with Franco-German cooperation potentially reinforced.

Cillian Ryan emphasizes the multiple reasons behind voters' behaviour on June 23rd and he addresses key economic aspects, namely that leading Brexit supporters such as Mr. Gove wanted to make the public believe that the traditional economic theories 
about trade and growth dynamics should no longer be taken seriously; i.e. that the digital economy's expansion implies that traditional trade arguments in favour of EU integration should not really be considered valid any longer. This conjecture of Mr. Gove, the Minister of Justice in the Cameron government, is totally misleading (distance has still not become irrelevant in the gravity equation for trade) and it could be that the banking crisis, anticipated by very few economists, had undermined the credibility of economists so much that economic nonsense such as the Gove No-Theory of Trade could sound credible to a public that had lost much confidence in part of the ruling elite. It is obvious that the pro-EU arguments were not well understood and that the Cameron government had enjoyed insufficient credibility.

Paul Welfens' contribution argues that the referendum result of June 23rd was very much distorted by the Cameron government's inability to convey to British households the government's own insights from a Treasury study on the long-term impact of EU membership (and - in a mirror perspective - BREXIT). The government sent out a 16page information brochure to all households from April 11th-13th, 2016, a week before the Treasury study with key insights on a potential BREXIT case was published: -6 percent expected GDP decline and another 4 percent output loss from the UK's nonparticipation in EU single market deepening added up to a -10 percent output loss as the cost of BREXIT. Applying the empirical results on popularity functions for the UK, dating back to the contribution of Frey/Schneider in the Economic Journal - and similar to methods employed in more recent studies - is very simple: had government, in line with its basic information duties, included the information that more than one month's income would be lost in the case of BREXIT, the result of the referendum, given this correct information procedure, would have been 52 percent for Remain. The Cameron government has proven to have been incapable of organizing a national referendum in a professional way and thus nobody can know what the majority of a well-informed British public really wants - the 'BREXIT means BREXIT' mantra of Prime Minister May sounds quite strange against this background.

That the May government is not taking British economic interests and the position of leading British companies much into account has become obvious in many ways and stands for a new contradictory approach by the Tory Party. There are new reasons to worry about the rationality of government in the UK. The Minister of Finance, Mr. Philip Hammond, who tried to restore calm after a flash devaluation of the British pound by 6 percent against the US \$ on October 6th, 2016, (the pound partly recovered the following day) by saying - according to the Financial Times of October 8th, page 1 - "that sterling's sudden fall was the sort of 'turbulence' he expected for the next five years". This is indeed a strange statement and forecast since it apparently suggests that the British BREXIT process will create financial market instabilities for many years to come; and should in stop in year six. It is completely unclear which new theory stands behind Mr. Hammond's statement.

If the UK should really leave the European Union, the future EU would be a group of countries that would henceforth be faced by the continuous risk that other countries could also leave the EU and indeed could actually team up with the UK in a new competing integration group. This in turn is bound to lead to efforts for deeper EU integration - no longer prevented by a hesitant UK - to counter-balance this new threat, the alternative could be a sustained EU disintegration process that ends up with much more nationalism across the whole of Europe, which would be to the advantage of 
some of the big Western countries, but Russia could certainly also make easy gains in the environment of a disintegrating EU. This means that the US cannot remain a bystander simply watching BREXIT and the following European dynamics from afar.

As regards the UK, one may follow the view of Harold James who anticipates that the British post-Brexit problems would be more serious than those of the EU after 2019. There is an interesting new perspective for the US whose currency appreciation vis-à-vis the Pound Sterling from mid-2015 to early October 2016 has been considerable and is likely to further increase in real terms: The "terms of capital", the international relative price of capital goods and firms, respectively, will fall to the disadvantage of the UK - US investors will be able to acquire British companies at a steep discount and China's investors, as well as investors from ASEAN countries, Japan and Korea, will enjoy a similar opportunity in the future. The UK could increasingly come under Asian influence and in any case the post-BREXIT political course of the May government is likely to follow a pro-globalization approach thus disappointing those voters who had expressed not only anti-EU feelings in the referendum of June 23rd but anti-globalization attitudes as well.

The rise of populism in many key EU countries could bring political instability and, in turn, more economic instability - with Germany being no exception. The refugee wave and the continuing terrorist threat facing many EU countries will translate into higher right-wing populist voting shares in upcoming national elections and cooperation among Europe's new right-wing groups is growing. From an economist's perspective, BREXIT is an original development, as it stands for modern disintegration and this is indeed a new phenomenon: EU disintegration will not only mean rolling back economic integration steps and the associated benefits, but also means partly destroying EU institutional capital. The fact that BREXIT is a doubtful decision from an economic perspective does not imply that the EU27 integration reforms will bring economic benefits. The EU can no longer argue that every crisis is just a new impulse for the further integration of the existing club the European Commission and the EU member countries' governments, often undermining progress with regard to EU integration, will now have to rethink the EU integration framework in many ways; not only regarding less regulation and only then EU deepening. The poor communication of both the European Commission and the EU Parliament also has to be improved and catching-up in social networks to the leading populist digital performance is a true challenge for the more traditional parties.

The next BREXIT Forum is scheduled for spring 2019 when the conditions under which BREXIT will take place will have become clear - if it takes place at all; if not, the May government will hardly survive and this would pose new economic questions and issues as well. We will all be witness to a historical BREXIT negotiation process which could last two years. The Bank of England is likely to keep interest rates very low for several years to come and this will reinforce the unusually low nominal and real interest rates in the whole EU. Companies and governments with high debt are bound to benefit in the medium term, in the long run, the unusually low interest rates tend to bring allocation inefficiencies and new potential financial market instabilities. Both the UK and the EU27 will be interested in avoiding a further crisis and this common interest alone could stimulate some new cooperation between London and Brussels. The EU without the UK will be economically weaker, probably more protectionist and possibly also more xenophobic than the EU28 before the UK referendum. 